ISSN 1392-3196

Zemdirbyste-Agriculture, vol. 100, No. 1 (2013), p. 19-24

UDK 631.437:631.465 / DOI 10.13080/z-a.2013.100.003

\title{
The effect of microbiological products on soil properties in the conditions of replant disease
}

\author{
Ziofa ZYDLIK, Piotr ZYDLIK \\ University of Life Sciences \\ Dąbrowskiego 159, 60-594 Poznań, Poland \\ E-mail: zydlik@au.poznan.pl,piotriw@au.poznan.pl
}

\begin{abstract}
The phenomenon of soil fatigue, causing replant disease, can occur in the conditions of monocultural cultivation. This evokes a decrease in the soil productive value because of the deterioration of biological soil properties. In the present work, an attempt has been made to improve the biological activity of a replanted soil by the use of three micro-biological preparations: EM-5, Bacto Fill 10B and Humobak PG. The biological activity of soil was estimated using two parameters: the activity of soil enzymes, dehydrogenase and protease as well as the respiratory activity. The application of microbiological preparations significantly increased the activity of dehydrogenase in the soil. The effect of two among the three applied preparations exerted a smaller influence on the protease activity. An exception was the Humobak PG preparation whose application distinctly increased the activity of protease in the replanted soil. On the other hand, the vegetation period was found to exert a significant effect both on soil enzymatic and respiratory activity. In the autumn period, the activity of both enzymes in the soil was higher, in comparison with the spring period, while the respiratory activity was higher in the spring. The functioning of soil microorganisms depends on some physico-chemical properties of soil. In our work, the studied preparations did not have any significant effect on the changes in the $\mathrm{pH}$ values. However, the effect was more perceivable on the content of organic carbon in the soil. The application of microbiological preparations in replanted soil caused a change in the plant growth and fruiting. Among others, an increase in the average leaf area of strawberry, the average fruit mass and the content of juice extract in fruits was observed.
\end{abstract}

Key words: enzymatic activity of soil, microbiological preparations, physico-chemical properties of soil, productivity of strawberry, replant disease, respiratory activity.

\section{Introduction}

A long-term growing of the same plant species in the same place in an orchard is called "monoculture". Such practice leads to the phenomenon known under the name of "soil fatigue", or "soil sickness" which causes the development of replantation disease (Manici et al., 2003; Szajdak, 2003; Zydlik, 2004). Replanted plants have greater difficulties in adapting to habitat conditions and they show worse growth parameters, in comparison with plants grown in localities not used earlier for the same species, i.e. in the so called "virgin soil" (Zydlik, 2004; Rumberger et al., 2007).

Soil micro-organisms belong to the basic factors contributing to the accessibility of nutritive components to plants (Paul, Clark, 2000). Monoculture continued for many years disturbs the biological balance in the soil (Szajdak, 2003) and changes the species composition of soil micro-organisms (Barabasz et al., 1998). In replanted soil, one can observe a decrease of beneficial bacteria and an increase of phytopathogenic and toxinogenic ones (Kowalik, 1999).
A limitation of the occurrence of replant diseases is possible by the application of agrotechnical treatments like mineral fertilization, particularly by nitrogen and watering (Zydlik, Pacholak, 2003). However, fertilization with high mineral fertilizer doses can decrease the activity of some soil enzymes (Bielińska, Węgorek, 2005; Bielińska et al., 2008). This fact forces the producers to more rationally apply chemical means and to replace them partially or totally by natural fertilizers which are incomparably less harmful to the environment. Natural fertilizers can represent preparations containing live organisms. One of such preparations is EM (effective microorganisms) used in ecological agriculture as a means improving the productive properties of soil. This preparation represents a mixture of naturally occurring micro-organisms: bacteria, mainly lactic acid, small number of photosynthetic bacteria and other organisms. There are positive opinions concerning the beneficial influence of the EM preparations on the vegetative growth of plants, improvement of plant general condition which contributes to their greater resistance to diseases 
and pests (Stewart, Daly, 1999). EM applied to the soil increases the diversity of soil micro-fauna (Hoshino et al., 2002); it limits the development of pathogenic organisms in the environment (Kaczmarek et al., 2008).

Other alternatives to chemical products are the following microbiological preparations: Bacto Fill 10B and Humobak PG. The first one contains specialized bacterial vaccine, macro and micro elements, enzymes and other active substances created by micro-organisms (plant hormones, vitamins, etc.). The second one is a mixture of multi-active saprophytic soil micro-organisms, bacteria, actinomycetes and fungi. According to the producers of these preparations, their use improves some physico-chemical properties of soil, increases the volume and mass of the plant root system, causes the increase of plant hormones and decreases the content of pathogenic soil micro-flora.

The objective of our work was to estimate the effect of three microbiological preparations on the selected biological and physico-chemical properties of soil as influence by the replant disease.

\section{Material and methods}

Our experiment was conducted at the Experimental Station of Fruit Growing Department, University of Life Sciences in Poznań, in the years 2009-2010. In spring 2009, cuttings of strawberry cultivar 'Senga-Sengana' were planted into plastic containers of 81 capacity. The containers were filled with two different types of soil. 1. Soil from orchard quarter not used, so far, for orchard purposes, but prepared for new plantation (virgin soil). The soil was characterized by physico-chemical properties optimal for the tested plants ( $\mathrm{pH}$ value between 5.5 and 6.5 and optimal $\mathrm{P}$, $\mathrm{K}$ and $\mathrm{Mg}$ content). 2. Soil from apple tree rows in the orchard quarter utilized for about 30 years as orchardreplanted soil. The fact of replant disease in this soil has been confirmed earlier (Zydlik, 2010). Results obtained in a series of studies carried out by the authors, in the years 2003-2005 indicate strawberry as a species which reacts in the quickest way to the chemical and biological properties of the replanted soil (Pacholak, Zydlik 2004; 2006). This fact decided that strawberry plants were selected as a test plant in the experiment.

The experiment included 5 treatments represented by 6 replications. Each replication consisted of one container with plants. The applied treatments were as follows: treatment 1 - soil prepared for orchard cultivation (control), treatment 2 - replanted soil, treatment 3 - soil from treatment 2 with EM-5 preparation, treatment 4 soil from treatment 2 with Bacto Fill 10B preparation, treatment 5 - soil from treatment 2 with Humobak PG preparation.

During the experiment, no additional mineral fertilization was applied. The basic treatments included a periodical plant irrigation and removal of weeds.

The EM-5 preparation is available on the market in the form of a concentrate named EM-1 from which preparations ready for use are made: EM-A (active) and EM-5. The EM-5 preparation was made for application in our experiment according to the recommendations of the producer. Water $(800 \mathrm{ml})$, the concentrate $(100 \mathrm{ml})$ and molasses $(100 \mathrm{ml})$ were mixed. After 7 days, $100 \mathrm{ml}$ of vinegar and $100 \mathrm{ml}$ of alcohol (40\%) were added. The preparation was ready to be applied after 14 days. The remaining two microbiological preparations did not require any additional procedure.

In the vegetation period, three soil applications of the preparation were carried out: the first one at the beginning of vegetation and the successive ones in onemonth intervals. The dose of EM-5 preparation was $10 \mathrm{ml} \mathrm{m}^{-2}$ in $50 \mathrm{ml}$ of water $\left(1001 \mathrm{ha}^{-1}\right.$ in 5001 of water, respectively). Humobak PG preparation was applied in one dose $15 \mathrm{~g} \mathrm{~m}^{-2}$ (1500 $\left.\mathrm{kg} \mathrm{ha}^{-1}\right)$. After spreading the preparation on soil surface, it was mixed with the soil in order to avoid the negative effect of sun radiation on the micro-organisms. The dose of Bacto Fill 10B was $0.1 \mathrm{ml} \mathrm{m}^{-2}$ (one litre per ha). Here also the preparation was mixed with the soil. In order to increase the efficacy of the microbiological preparations, spraying was carried out in the morning and in the evening, during the period of high air humidity.

Soil samples were taken in June and September, in each experimental year. From each replication within the treatment, one sample of $0.2 \mathrm{~kg}$ was taken. The samples were analysed for: 1) organic carbon content (content of organic matter), 2) soil $\mathrm{pH}, 3$ ) activity of two enzymes: dehydrogenase and protease, 4) respiratory activity of soil.

The content of organic carbon was studied by Tiurin's method. The measurement of soil $\mathrm{pH}$ was done by the potentiometric method. Respiratory and enzymatic activities of soil, next to such parameters as the total number of micro-organism groups, are regarded as reliable indicators of soil micro-flora activity (Kucharski, 1997). Respiratory activity in field conditions was determined on the basis of the released $\mathrm{CO}_{2}$ by the absorption method $\left(\mathrm{CO}_{2}\right.$ in $\left.\mathrm{mg}^{-1} \mathrm{~kg}^{-1} 48 \mathrm{~h}^{-1}\right)$ (Gołębiowska, Pędziwilk, 1984). Enzymatic activity of soil was determined by the following methods: 1) protease (AP) - by spectrophotometric method according to Ladd and Butler (1972) using 1\% sodium caseinate after $1 \mathrm{~h}$ of incubation at $50^{\circ} \mathrm{C}$ and $578 \mathrm{~nm}$ wave length, 2) dehydrogenase (ADh) - by colorimetric method according to Thalmann (1968) using 1\% of triphenyltetrazolium chloride (TTC) solution, after $24 \mathrm{~h}$ of incubation at $30^{\circ} \mathrm{C}$ and $485 \mathrm{~nm}$ wave length (TTC test).

Leaves of strawberry plants were collected at the end of their vegetation period, before they started to fall down. From each treatment, 30 leaves were taken (5 leaves from each replication). The leaf area was defined using a scanner and the digiShape computer program.

The evaluation of the yielding and fruit quality included the measurement of fruit mean mass, firmness and extract content. From each combination, a representative sample of 15 fruits was collected and then, they were weighed. For the measurement of extract and fruit firmness, an automatic firmness meter and an electronic calorimeter were used. All measurements were carried out on the same plants and fruit. 
The obtained results were statistically processed. For this purpose, one or two-factor analysis of variance was applied and Duncan's test was used at the significance level of $\alpha=0.05$. Results were analyzed on the basis of mean values for the treatments from the years 2009-2010.

\section{Results}

The replanted soil used in the experiment was characterized by worse agrochemical properties (except for soil $\mathrm{pH}$ ) in comparison with the soil not utilised as orchard (control). The reaction of the replanted soil was more acid and the percentage content of organic carbon was significantly lower (Table 1). Microbiological preparations modified these parameters. Their application significantly changed the soil $\mathrm{pH}$ and increased organic carbon in the soil (Table 1). Also the enzymatic activity was lower, in comparison with the control. Before the application of microbiological preparations (in the stage of experiment establishment) both the activity of dehydrogenase $\left(5.29 \mathrm{~cm}^{3} \mathrm{H}_{2} \mathrm{~g}^{-1} 24 \mathrm{~h}^{-1}\right.$ dry mass (d.m.) of soil) and protease ( $7.04 \mathrm{mg}$ tyrosine, $\mathrm{g}^{-1} \mathrm{~h}^{-1}$ d.m. of soil) in the soil of the control treatment was visibly higher, in comparison with the activity of those enzymes in the soil exhibiting symptoms of replant disease $\left(1.57 \mathrm{~cm}^{3} \mathrm{H}_{2} \mathrm{~g}^{-1}\right.$ $24 \mathrm{~h}^{-1} \mathrm{~d} . \mathrm{m}$. of soil and $4.83 \mathrm{mg}$ tyrosine, $\mathrm{g}^{-1} \mathrm{~h}^{-1} \mathrm{~d} . \mathrm{m}$. of soil, respectively).

The application of each of the three studied microbiological preparations to the soil increased the enzymatic activity in the replanted soil, particularly that of dehydrogenase (Table 1). Humobak PG preparation exhibited the most significant effect on the activity of soil. Its application caused an increase in dehydrogenase activity in the soil to $8.48 \mathrm{~cm}^{3} \mathrm{H}_{2} \mathrm{~g}^{-1} 24 \mathrm{~h}^{-1} \mathrm{~d}$. m. of soil which represented a 5-fold increase of this enzyme activity in the replanted soil (without the use of microbiological preparations) (Table 1).

The influence of microbiological preparations on the change of protease activity in the soil was lower. The application of preparations EM-5 and Bacto Fill $10 \mathrm{~B}$ did not result in a significant increase in the activity of this enzyme in the replanted soil; in comparison both with the control treatment and with the treatment with replanted soil but not treated with microbiological preparations (Table 1). The application of Humobak PG significantly increased the activity of protease $(9.76 \mathrm{mg}$ tyrosine, $\mathrm{g}^{-1} \mathrm{~h}^{-1} \mathrm{~d} . \mathrm{m}$. of soil), in comparison with the activity of this enzyme in the other treatments.

Table 1. Agrochemical and biological properties of soil treated with biological preparations

\begin{tabular}{|c|c|c|c|c|}
\hline \multirow[b]{2}{*}{ Treatments } & \multirow[b]{2}{*}{$\begin{array}{c}\text { Soil pH } \\
\text { (pH KCl) }\end{array}$} & \multirow{2}{*}{$\begin{array}{l}\text { Organic } \\
\text { carbon } \\
\text { content }\end{array}$} & \multicolumn{2}{|c|}{ Enzymatic activity } \\
\hline & & & $\begin{array}{c}\text { dehydro- } \\
\text { genase }\end{array}$ & protease \\
\hline Control & $6.63 \mathrm{~d}^{*}$ & $0.99 \mathrm{c}$ & $5.34 \mathrm{c}$ & $6.34 \mathrm{~b}$ \\
\hline Replanted soil & $6.28 \mathrm{~b}$ & $0.67 \mathrm{a}$ & $1.63 \mathrm{a}$ & $4.91 \mathrm{a}$ \\
\hline EM-5 & $6.21 \mathrm{~b}$ & $0.84 \mathrm{bc}$ & $3.61 \mathrm{~b}$ & $5.76 \mathrm{ab}$ \\
\hline Bacto Fill 10B & $6.07 \mathrm{a}$ & $0.79 \mathrm{ab}$ & $3.73 \mathrm{~b}$ & $5.16 \mathrm{a}$ \\
\hline Humobak PG & $6.43 \mathrm{c}$ & $0.92 \mathrm{bc}$ & $8.48 \mathrm{~d}$ & $9.75 \mathrm{c}$ \\
\hline
\end{tabular}

Note. ${ }^{*}$ - means in the columns, marked with the same letters do not differ significantly at the level of probability $\alpha=0.05$.
Dehydrogenase activity varied significantly with time (sampling date). In September, the dehydrogenase activity in the soil $\left(5.47 \mathrm{~cm}^{3} \mathrm{H}_{2} \mathrm{~g}^{-1} 24 \mathrm{~h}^{-1}\right.$ d.m. of soil) was significantly higher, in comparison with that in June (3.64 $\mathrm{cm}^{3} \mathrm{H}_{2} \mathrm{~g}^{-1} 24 \mathrm{~h}^{-1}$ d.m. of soil) (Table 2).

Table 2. The dehydrogenase activity $\left(\mathrm{cm}^{-3} \mathrm{H}_{2} \mathrm{~g}^{-1} 24 \mathrm{~h}^{-1} \mathrm{~d} . \mathrm{m}\right.$. of soil) in the soil treated with biological preparations

\begin{tabular}{cccc}
\hline \multirow{2}{*}{ Treatments } & \multicolumn{2}{c}{ Soil sampling date } & $\begin{array}{c}\text { Average for } \\
\text { treatments }\end{array}$ \\
\cline { 2 - 4 } & June & September & $5.34 \mathrm{c}$ \\
\hline Control & $4.08 \mathrm{c}^{*}$ & $6.61 \mathrm{e}$ & $1.63 \mathrm{a}$ \\
Replanted soil & $0.48 \mathrm{a}$ & $2.78 \mathrm{~b}$ & $3.61 \mathrm{~b}$ \\
EM-5 & $2.02 \mathrm{~b}$ & $5.20 \mathrm{~d}$ & $3.73 \mathrm{~b}$ \\
Bacto Fill 10B & $4.67 \mathrm{~cd}$ & $2.79 \mathrm{~b}$ & $8.48 \mathrm{~d}$ \\
Humobak PG & $6.98 \mathrm{e}$ & $9.98 \mathrm{f}$ & \\
\hline $\begin{array}{c}\text { Average for } \\
\text { soil sampling date }\end{array}$ & $3.64 \mathrm{a}$ & $5.47 \mathrm{~b}$ & \\
\hline
\end{tabular}

Explanations under Table 1

Also the activity of protease in the soil in the autumn period (7.0 mg tyrosine, $\mathrm{g}^{-1} \mathrm{~h}^{-1} \mathrm{~d}$.m. of soil) was significantly higher, in comparison with its activity in the early summer (5.62 $\mathrm{mg}$ tyrosine, $\mathrm{g}^{-1} \mathrm{~h}^{-1} \mathrm{~d} . \mathrm{m}$. of soil) (Table 3).

Table 3. The protease activity (mg tyrozyne $\mathrm{g}^{-1} \mathrm{~h}^{-1} \mathrm{~d}$. $\mathrm{m}$. of soil) in the soil treated by biological preparations

\begin{tabular}{cccc}
\hline \multirow{2}{*}{ Treatments } & \multicolumn{2}{c}{ Soil sampling date } & $\begin{array}{c}\text { Average for } \\
\text { treatments }\end{array}$ \\
\cline { 2 - 3 } & June & September & $5.48 \mathrm{~b}$ \\
\hline Control & $7.21 \mathrm{c}^{*}$ & $6.34 \mathrm{~b}$ \\
Replanted soil & $3.35 \mathrm{a}$ & $6.48 \mathrm{bc}$ & $4.91 \mathrm{a}$ \\
EM-5 & $5.31 \mathrm{~b}$ & $6.21 \mathrm{bc}$ & $5.76 \mathrm{ab}$ \\
Bacto Fill 10B & $3.41 \mathrm{a}$ & $6.91 \mathrm{bc}$ & $5.16 \mathrm{a}$ \\
Humobak PG & $8.84 \mathrm{~d}$ & $10.66 \mathrm{e}$ & $9.75 \mathrm{c}$ \\
\hline $\begin{array}{c}\text { Average for } \\
\text { soil sampling date }\end{array}$ & $5.62 \mathrm{a}$ & $7.15 \mathrm{~b}$ & \\
\hline
\end{tabular}

Explanations under Table 1

The applied microbiological preparation did not change the respiratory activity of soil. Both in the control and in the soil from the remaining treatments, the respiratory activity was similar and it did not differ significantly (Table 4). The respiratory activity of soil was significantly higher in the early summer - 117.49 $\mathrm{CO}_{2} \mathrm{mg}^{-1} \mathrm{~kg}^{-1} 48 \mathrm{~h}^{-1}$, than in September - 77.12 $\mathrm{CO}_{2}$ $\mathrm{mg}^{-1} \mathrm{~kg}^{-1} 48 \mathrm{~h}^{-1}$.

Achange in the biological parameters of replanted soil, resulting from the application of microbiological preparations exerted an influence on the vegetative growth of the tested plants and their yielding and also on the fruit quality. The average leaf area of plants grown in a replanted soil treated with microbiological preparations, and particularly with EM-5 $\left(41.8 \mathrm{~cm}^{2}\right)$, was grater, in comparison with treatments, where the preparations were not applied $\left(38.3 \mathrm{~cm}^{2}\right)$ (dates not presented). 
Table 4. The respiratory activity $\left(\mathrm{CO}_{2} \mathrm{mg}^{-1} \mathrm{~kg}^{-1} 48 \mathrm{~h}^{-1}\right)$ of the soil treated with biological preparations

\begin{tabular}{|c|c|c|c|}
\hline \multirow{2}{*}{ Treatments } & \multicolumn{2}{|c|}{ Soil sampling date } & \multirow{2}{*}{$\begin{array}{c}\text { Average for } \\
\text { treatments }\end{array}$} \\
\hline & June & September & \\
\hline Control & $111.90 \mathrm{~d}^{*}$ & $75.16 \mathrm{a}$ & $97.14 \mathrm{a}$ \\
\hline Replanted soil & $121.69 \mathrm{~d}$ & $71.53 \mathrm{a}$ & $96.61 \mathrm{a}$ \\
\hline EM-5 & $110.46 \mathrm{~cd}$ & $64.46 \mathrm{a}$ & $59.96 \mathrm{a}$ \\
\hline Bacto Fill 10B & $104.37 \mathrm{~b}-\mathrm{d}$ & $89.34 \mathrm{a}-\mathrm{c}$ & $96.85 \mathrm{a}$ \\
\hline Humobak PG & $131.83 \mathrm{~d}$ & $80.11 \mathrm{ab}$ & $105.97 \mathrm{a}$ \\
\hline $\begin{array}{c}\text { Average for } \\
\text { soil sampling date }\end{array}$ & $116.05 \mathrm{~b}$ & $76.12 \mathrm{a}$ & \\
\hline
\end{tabular}

Explanations under Table 1

The mass of strawberry fruits grown in the soil treated with the tested preparations was significantly greater than in the treatment with replanted soil, where the preparations were not applied (Table 5). For example after EM-5 application, the fruits had a greater mass $(7.18 \mathrm{~g})$ than in the control treatment, where the soil did not show any disease symptoms $(6.79 \mathrm{~g})$.

In most cases, in the fruits collected from plants grown in a replanted soil treated with microbiological preparations, the content of extract was significantly higher than in the treatment without preparations, with the exception of the fruit firmness, where such relationship was not observed (Table 5).

Table 5. Yielding and quality of strawberry fruits grown in the soil treated with microbiological preparations in the years 2009-2010

\begin{tabular}{cccc}
\hline Treatments & $\begin{array}{c}\text { Fruit } \\
\text { mass } \\
\mathrm{g}\end{array}$ & $\begin{array}{c}\text { Content of } \\
\text { extract } \\
\%^{\circ} \text { Brixa }\end{array}$ & $\begin{array}{c}\text { Fruit firmness } \\
\mathrm{G} \mathrm{mm}^{-1}\end{array}$ \\
\hline Control & $6.79 \mathrm{~b}^{*}$ & $11.59 \mathrm{~b}$ & $124.5 \mathrm{a}$ \\
Replanted soil & $5,73 \mathrm{a}$ & $10.27 \mathrm{a}$ & $120.7 \mathrm{a}$ \\
EM-5 & $7,18 \mathrm{~d}$ & $11.26 \mathrm{~b}$ & $116.6 \mathrm{a}$ \\
Bacto Fill 10B & $6.92 \mathrm{bc}$ & $10.89 \mathrm{ab}$ & $122.5 \mathrm{a}$ \\
Humobak PG & $6.87 \mathrm{bc}$ & $11.15 \mathrm{~b}$ & $129.4 \mathrm{a}$ \\
\hline
\end{tabular}

Explanations under Table 1

\section{Discussion}

One of the indices showing changes in the biological properties of soil is the level of the soil enzymatic activity. According to Bielińska and Węgorek (2005), enzymatic tests are recognized as some of the more sensitive indicators of the correct functioning of ecosystems. Results presented in our work indicate a positive effect of the microbiological preparations applied to the soil. They contributed to the increase of dehydrogenase activity in the soil. However, their influence on protease activity was less noticeable. Kaczmarek et al. (2008) also stressed the positive effect of EM preparations on the activity of soil dehydrogenase. A higher enzymatic activity of soil through its participation in the organic matter decomposition exerts a positive effect on the growth and development of plants.

An essential influence on the activity of soil enzymes, next to the actual method of soil utilization, is exerted by the climatic factors. Enzymatic activity decreases with an increase in air temperature and a decrease in moisture content in the soil (Insam et al., 1989). In our experiment, dehydrogenase and protease activity in the soil was higher during the autumn period. Similar relationships were found in the experiments of Bielińska (2001), Russel (2005) and Zydlik (2010). The occurrence of anaerobic bacteria in the soil had a significant influence on the activity of dehydrogenase. Therefore, their activity increases in anaerobic conditions resulting among others from a presence of a great amount of water in the soil. Data from the meteorological station based in the experimental site indicate that in the year 2010, both in August (118.0 mm) and in September (81.4 $\mathrm{mm})$, there fell twice as much rain-fall as the perennial average (61.5 and $40.9 \mathrm{~mm}$, respectively). This factor could have an influence on the activity of dehydrogenase in the soil.

Next to the climatic conditions, the enzymatic activity of soil can be influenced by some physicochemical properties. They can include, among others, the content of mineral and organic colloids, temperature and soil pH (Kucharski, Jastrzębska, 2001). Barabasz and Vořišek (2002) argued that a decrease of soil acidity leads to the limitation of biodiversity of soil microflora, which causes lower soil enzymes activity. The microbiological preparations used in our experiment had a low influence on the $\mathrm{pH}$ value of the replanted soil. However, they contributed to the increase of organic carbon in the soil. This could have resulted indirectly from the organic nutrients present in the tested preparations, on which the micro-organisms develop. A higher content of organic matter in the soil is favourable for its enzymatic activity through the creation of complexes with enzymes which thereby become more resistant to denaturation (Aon, Colaneri, 2001).

$\mathrm{CO}_{2}$ released from the soil originates mainly from organic matter decomposed by soil micro-organisms. Therefore, the respiratory activity is recognized as an indicator of a general microbiological activity of soil. In our experiment, the application of microbiological preparations to the soil did not increase significantly its respiratory activity. In the early summer period, the respiratory activity of soil was distinctly higher, in comparison with the autumn period.

Different level of the respiratory activity, in different vegetation periods, may result from the influence of climatic conditions. Temperature increase intensifies the activity of soil micro-organisms accelerating the $\mathrm{CO}_{2}$ release. Another significant factor is the soil moisture. Both with low and with very high moisture, the respiratory activity of soil decreases (Kieliszewska-Rokicka, 2001). Low soil moisture does not provide a sufficient access of microorganisms to water, while moisture excess causes an insufficient access to oxygen. In the year 2010, the mean monthly temperature in September $\left(12.2^{\circ} \mathrm{C}\right)$ was lower than the perennial average $\left(14.9^{\circ} \mathrm{C}\right)$. In combination with a high level of soil moisture, this fact might have 
created less favourable atmospheric conditions for the development of soil micro-organisms in the autumn period and this, in turn, could have resulted in a lower respiratory activity of the soil in that period.

\section{Conclusions}

1. A statistically significant influence of the microbiological preparations on the increase of dehydrogenase activity in the soil was found.

2. The use of EM-5 and Bacto Fill 10B preparations did not cause any increase in the activity of protease in the replanted soil.

3. The activity of both dehydrogenase and protease as well as respiratory activity of soil in the autumn period was significantly higher, in comparison with the early summer period.

4. The application ofmicrobiological preparations did not exert any significant influence on the respiratory activity of soil from former apple tree orchard.

5. The application of microbiological preparations in the soil from former apple tree orchard significantly increased the mean mass of strawberry fruits and the extract content in them. However, no significant influence on the fruit firmness was found.

Received 05042012 Accepted 04022013

\section{References}

Aon M. A., Colaneri A. C. 2001. Temporal and spatial evolution of enzymatic activities and physico-chemical properties in an agricultural soil. Applied Soil Ecology, 18: 255-270 http://dx.doi.org/10.1016/S0929-1393(01)00161-5

Barabasz W., Smyk B., Chmiel M. J., Vořišek K. 1998. Zmęczenie gleb, a skład mikroflory glebowej. Ekologiczne aspekty mikrobiologii gleby. Poznań, Poland, p. 43-56 (in Polish)

Barabasz W., Vořišek K. 2002. Bioróżnorodność mikroorganizmów w środowiskach glebowych. Aktywność drobnoustrojów w różnych środowiskach. Kraków, Poland, p. 23-24 (in Polish)

Bielińska E. J. 2001. Aktywność enzymatyczna gleby w sadzie wiśniowym w zależności od metody pielęgnacji. Rozprawy Naukowe Akademii Rolniczej w Lublinie, 251: 5-110 (in Polish)

Bielińska E. J., Węgorek T. 2005. Aktywność enzymatyczna gleby użytkowanej sadowniczo jako wskaźnik stanu środowiska wywołany stosowaniem ściółek z tworzyw sztucznych. Acta Agrophysica, 5: 17-24 (in Polish)

Bielińska E. J., Futa B., Mocek A. 2008. Wpływ zabiegów agrotechnicznych na funkcjonowanie krajobrazu rolniczego. Inżynieria Rolnicza, 10 (108): 7-15 (in Polish)

Gołębiowska J., Pędziwilk Z. 1984. $\mathrm{CO}_{2}$ release as on index of biological activity of cultivated soils. Acta Microbiologica Polonica, 33: 249-256

Hoshino Y., Satou N., Higa T. 2002. Remediation and preservation of natural ecosystems through application of effective microorganisms $(\mathrm{EM})$ : proceedings of $7^{\text {th }}$ International Conference on Kyusei Natural Farming. New Zealand, p. 129-137

Insam H., Parkinson D., Domsch K. H. 1989. Influence of macroclimate on soil microbial biomass. Soil Biology and
Biochemistry, 21: 211-221

http://dx.doi.org/10.1016/0038-0717(89)90097-7

Kaczmarek Z., Wolna-Murawka A., Jakubs M. 2008. Changes of the number of selected microorganism groups and enzymatic activity in the soil inoculated with effective microorganism (EM). Journal of Research and Applications Agricultural Engineering, 53 (3): 122-127

Kieliszewska-Rokicka B. 2001. Enzymy glebowe i ich znaczenie w badaniach aktywności mikrobiologicznej gleby. Drobnoustroje środowiska glebowego. Aspekty fizjologiczne, biochemiczne, genetyczne. Toruń, Poland, p. 37-47 (in Polish)

Kowalik M. 1999. Soil fungi and the replant disease in an apple orchard. Phytopathologia Polonica, 17: 31-40

Kucharski J. 1997. Relacje między aktywnością enzymów a żyznością gleby. Drobnoustroje w środowisku. Wystepowanie, aktywność i znaczenie. Kraków, Poland, p. 327-347 (in Polish)

Kucharski J., Jastrzębska E. 2001. Aktywność enzymatyczna gleby zanieczyszczonej olejem napędowym. Zeszyty Problemowe Postępu Nauk Rolniczych, 476: 181-187 (in Polish)

Ladd N., Butler J. H. A. 1972. Short-term assays of soil proteolytic enzyme activities using proteins and dipeptide derivatives as substrates. Soil Biology and Biochemistry, 4: 19-30 http://dx.doi.org/10.1016/0038-0717(72)90038-7

Manici L. M., Ciavatta C., Kelderer M., Erschbaumer G. 2003. Replant problems in South Tyrol: role of fungal pathogenes and microbial population in conventional and organic apple orchards. Plant and Soil, 256: 315-324 http://dx.doi.org/10.1023/A:1026103001592

Pacholak E., Zydlik Z. 2004. Effect of soil locality on the growth of strawberry plants grown in rhizoboxes. Sodininkyste ir daržininkystè, 23 (2): 388-394

Pacholak E., Zydlik Z. 2006. Effect of locality on the growth of strawberries grown in rhizoboxes in the year 2003-2004. Latvian Journal of Agronomy, 9: 93-97

Paul E. L., Clark F. 2000. Mikrobiologia i biochemia gleb. Lublin, Poland, p. 100-130 (in Polish)

Rumberger A., Merwin I. A., Thies J. E. 2007. Microbial community development in the rhizosphere of apple trees at a replant disease site. Soil Biology and Biochemistry, 39 (7): $1645-1654$

http://dx.doi.org/10.1016/j.soilbio.2007.01.023

Russel S. 2005. Znaczenie badań enzymów w środowisku glebowym. Acta Agrophysica, Rozprawy i Monografie, 3: 5-9 (in Polish)

Stewart D. P. C., Daly M. J. 1999. Influence of "effective microorganisms" (EM) on vegetable production and carbon mineralization - a preliminary investigation. Journal of Sustainable Agriculture, 14 (2): 3-15

Szajdak L. 2003. Substancje biologicznie czynne w glebach spod wieloletniej monokultury żyta i spod zmianowania. Postępy Nauk Rolniczych, 1: 3-16 (in Polish)

Thalmann A. 1968. Zur methodik der bestimmung der dehydrogenase aktivitat in boden mittels triphenyltetrazoliumchlorid (TTC). Landwirtsch. Forsch, 21: 249-258 (in German)

Zydlik Z. 2004. Effect of locality on the microbiological condition of soil from replanted apple orchard. Folia Universitatis Agricultura Stetinensis, 96: 219-224

Zydlik Z. 2010. Właściwości mikrobiologiczne i biochemiczne gleby oraz wzrost i plonowanie jabłoni po replantacji. Rozprawy Naukowe Uniwersytetu Przyrodniczego w Poznaniu, 412: p. 33-82 (in Polish)

Zydlik Z., Pacholak E. 2003. Wpływ zróżnicowanego nawożenia i nawadniania na jakość owoców oraz zdolność przechowalniczą jabłek odmiany Šampion. Prace Komisji Nauk Rolniczych i Leśnych, 95: 297-302 (in Polish) 
ISSN 1392-3196

Zemdirbyste-Agriculture, vol. 100, No. 1 (2013), p. 19-24

UDK 631.437:631.465 / DOI 10.13080/z-a.2013.100.003

\title{
Mikrobiologinių produktų poveikis gentiškai nualinto dirvožemio savybẻms
}

\author{
Z. Zydlik, P. Zydlik \\ Lenkijos gyvybès mokslų universitetas
}

\section{Santrauka}

Dirvožemio nuovargis, sukeliantis ligas, susijusias su jo gentiniu nualinimu, gali atsirasti braškes auginant kaip monokultūrą. Dėl suprastėjusių dirvožemio biologinių savybių sumažẻja jo produktyvumas. Tyrimo metu siekta pagerinti biologinị dirvožemio, kuriame pasireiškia ligos, susijusios su jo gentiniu nualinimu, aktyvumą naudojant mikrobiologinius preparatus EM-5, Bacto Fill 10B ir Humobak PG. Dirvožemio biologinis aktyvumas vertintas pagal du rodiklius: dirvožemio fermentų dehidrogenazès bei proteazès ir kvėpavimo aktyvumą. Mikrobiologinių preparatų naudojimas smarkiai padidino dehidrogenazės aktyvumą dirvožemyje. Dviejų iš trijų naudotų preparatų poveikis darè mažesnę ịtaką proteazès veiklai. Išimtis - preparatas Humobak PG; jị panaudojus smarkiai padidèjo proteazès aktyvumas dirvožemyje, kuriame buvo ligų, susijusių su jo gentiniu nualinimu. Kita vertus, vegetacijos laikotarpis turèjo didelę įtaką ir dirvožemio fermentų, ir kvėpavimo aktyvumui. Rudens laikotarpiu abiejų fermentų aktyvumas dirvožemyje buvo didesnis, palyginus su pavasario laikotarpiu, o kvėpavimo aktyvumas buvo didesnis pavasarị. Dirvožemio mikroorganizmų funkcionavimas priklauso nuo jo fizikinių ir cheminių savybių. Tirti preparatai neturèjo esminio poveikio dirvožemio $\mathrm{pH}$ verčių svyravimui, tačiau jų poveikis buvo didesnis organinės anglies kiekiui dirvožemyje. Mikrobiologinių preparatų naudojimas dirvožemyje, kuriame buvo ligų, susijusių su jo gentiniu nualinimu, turèjo įtakos augalų augimui ir derejjimui. Nustatytas braškių vidutinio lapo ploto padidejjimas, taip pat vaisiaus vidutinès masės ir sulčių ekstrakto vaisiuose padidejjimas.

Reikšminiai žodžiai: braškių produktyvumas; dirvožemio fermentų veikla; dirvožemio fizikinès ir cheminès savybès; kvėpavimo aktyvumas; ligos, susijusios su dirvožemio gentiniu nualinimu; mikrobiologiniai preparatai. 